


\title{
Governmental propaganda in Mexican comics. The case of El Libro Vaquero.
}

\author{
BY: Iván Facundo Rubinstein and \\ Laura Nallely Hernández Nieto
}

\begin{tabular}{l} 
\\
\hline ARTICLE INFO: \\
\hline Volume: 06 \\
\hline Issue: 02:2020 \\
\hline Month: March \\
\hline ISSN: 2459-2943 \\
\hline DOl: 10.18680/hss.2020.0029 \\
\hline Pages: 207-228 \\
\hline Lic.: CC BY-NC-ND 4.0 \\
\hline KEYWORDS: \\
\hline communication \\
\hline propaganda \\
\hline Mexio-semiotics comics \\
\hline
\end{tabular}

ABSTRACT

ГT his article aims to analyze comic books' use as vehicles for 1 political communication. Employing socio-semiotic methodology, we describe the discursive operations utilized to disseminate governmental propaganda (a particular type of political communication) in Mexican popular culture. Our corpus comprises institutionally commissioned comic inserts in one of the most iconic magazines of contemporary Mexico: El Libro Vaquero ['The Cowboy Book']. According to our findings, these comics tend to make citizens primarily responsible for implementing public policy, ignore the structural causes of the social problems they represent, reducing them to a sum of individual issues, and, finally, downplay state responsibilities while painting a positive image of the different State institutions. Consequently, we should take these comics as a type of institutional propaganda rather than as social marketing.

\section{Introduction}

This article examines comic books' uses as political communication vehicles by governmental institutions during the last decade in Mexico. Employing socio-semiotic methodology, we describe the discursive operations utilized in these popular media to disseminate political messages. Focusing on four issues of the institutional comic series El Libro Vaquero ['The Cowboy Book'], we conduct a formal analysis of the narrative structure and representation of environmental problems, corruption, food hygiene, and the population consequently affected. 
Political communication studies take either a theoretical approach or a more empirical one. The former elaborates different models of understanding political communication's specificity, whereas the latter develop descriptive works about contemporary democracies' specific issues. The theoretical approaches include Niffenegger's model of the four Ps (product, promotion, price, and place), rooted in traditional marketing theory; Reid's model of buyer decision-making processes; Kotler and Kotler's six-stage model of the marketing process, as applied to political campaigns; Harris's model, which incorporates new elements, such as the personalization of politics and public relations; and Newman's model, which distinguishes between the marketing campaign and the political campaign as two different processes of political marketing (Cwalina, Falkowski and Newman 2011: 30ff).

The relation between marketing and politics has also been studied using LeesMarshment's market-oriented party model, which proposes three basic political party types: the product-, sales-, and the market-oriented party (Lees-Marshment 2002). Product orientation can be understood as the old-style programmatic campaigns based on the party's platform for action. In contrast, the sales and the market orientations refer to different political communication concepts. The former refers to the type of communication that focuses on the spread of pre-conceived messages: propaganda, involving the use of marketing tools to spread the demand for voting (Pratkanis 1991; Alboury 1994; Lilleker 2006: 163-4). The latter refers to the type of communication that utilizes marketing research tools to develop the message's structure and content before planning its dissemination (Kotler and Kotler 1999; Lees-Marshment 2002; Henneberg and O'Shaughnessy 2008).

Models of political communication also tend to focus on the importance of the internal party mechanism during election periods (Ormrod 2008; Lamprinakou 2008) or the use of marketing-oriented models for social marketing (Akbar and Lawson 2019). From this point of view, social marketing refers to using marketing tools to change people's behavior to reach a greater good, such as having healthy food, quitting smoking, doing exercise, stopping discrimination, etc. Therefore, while propaganda and political marketing aim to secure people's votes, social marketing aspires to modify unsustainable social behavior. Scholars have recently stressed the need for social marketing to pursue systemic problems by focusing not on individuals but all citizens and collective behavioral change (Rundle-Thiele et al. 2019).

Empirical approaches to political communication focus on specific phenomena in our democracies, such as spots, television debates, the uses of social media, or the relation of politicians with journalists and digital technologies, especially the internet (Kellner 2009; Coleman 2012; Lee 2012; Kruikemeier 2014; Fuchs 2019; Pickard and Berman 2019). In our age of multimodality, there is noticeable stress on studying political communication's specifically visual nature (Yu 2020). From that viewpoint, the study 
of a popular product such as the comic book and its uses as a political communication vehicle appears to be the right choice.

The political dimension of comics has been studied from different perspectives: the teaching of political issues to schoolchildren (Dougherty 2003; Woodcock 2006), the understanding of comics as a type of political journalism (Vanderbeke 2010), the sociosemiotic analysis of the representation of Pakistani women in webcomics (Sanaa and Sarwet 2014), or the uses of comics in electoral campaigns (Brantner and Lobinger 2014). Comic books have also been examined as cultural objects enabling the rethinking and critique of a traumatic historical event - such as war, totalitarianism, and dictatorship - (Mitaine and Alary 2011; Rosch 2013; Barker and Sabin 2012; Magnussen 2014), and systematically involved in cultural politics and power relations (Packard 2014; Cortsen, La Cour, and Magnussen 2015).

However, there is a gap regarding the governmental uses of comic books, i.e., comic books as a communication vehicle not by political parties but by state institutions. Our study examines the political content of one of the most iconic comic books in contemporary Mexico, the fortnightly El Libro Vaquero, with a circulation of 120.000 copies. On account of its wide-ranging popularity, institutional comics were inserted in the end pages of the publication.

The article comprises four sections. The first describes the history of Mexican comics and their importance in popular culture. The second examines El Libro Vaquero's current importance and uses as an advertising and propaganda vehicle. The third describes the methodology employed to analyze the four comics selected, and finally, the fourth section summarizes our analysis's main findings.

\section{Propaganda and the educational comic in Mexico}

The first comics in Mexico appeared in the pages of the Sunday supplements in the 1920s. Soon after, they moved away from American influence and became 'Mexicanized,' adopting the language of the citizens' daily life and incorporating characters with whom the population could identify.

A decade later, the so-called Golden Age of the Mexican comic began. It was inaugurated in 1934, with the publication of Paquin, the first miscellaneous comic book magazine in the country, and followed by Pepin and Chamaco in 1936. The government's literacy campaigns favored the appearance of many comic books (Aurrecoechea and Bartra 1993:181), besides the comics published in the dailies and Sunday papers. At the peak of comics' popularity, iconic series were born, like La Familia Burrón ['The Burrón Family']. During that stage, there were only a few comics with propagandistic content, e.g., El Maestro Mexicano ['The Mexican Teacher'], produced by the Secretariat of Public 
Education and published in Chamaco in 1945. This comic presented the teacher as a "cultural hero and an apostle of the alphabet" (Aurrecoechea and Bartra 1993:23). Another case is Segurito, published in Pepin in 1947. The Mexican Institute of Social Security created this character to encourage people to attend the institution's hospitals in the face of a smear press campaign engineered by the business class, which opposed establishing a social security policy (Hernández Nieto 2020).

The Society of Jesus published the comics magazine Chiquitin (1945-1963), which promoted Christian values and propagandized the Catholic version of universal and Mexican History. From 1954 to 1972, they also published Vidas ejemplares ['Exemplary Lives'], devoted exclusively to saints' lives and other Catholic Church's exemplars. Both these comic magazines were directed by Jesuit clergy (Pepines UNAM 2020).

The subsequent, so-called Silver Age of the Mexican comic began in the mid-1950s and culminated in the early 1980s. During this stage, some of the most popular series were Kalimán and Lágrimas, Risas y Amor ['Tears, Laughter and Love'] and El Libro Vaquero ['The Cowboy Book']. The cartoonist Eduardo del Río 'Rius' stands out as the initiator of the didactic comic in Mexico. In the 1960s, Rius created the magazine Los Agachados (1968-1981), addressing various political, scientific, and humanistic issues in a comic format. Del Río's criticism of the government cost him a mock execution, ordered by the then-President Gustavo Díaz Ordaz. Later on, with Marx para Principiantes ['Marx for Beginners'] (1976), he started the popular illustrated books' collection Para principiantes (Gómez Romero 2019: 21).

In 1966, the Secretariat of Public Education published Relámpago ['Lighting'], a magazine featuring passages on Mexico's history. Between 1981 and 1982, the Secretariat undertook an ambitious comic publishing program to introduce readers to the world of literature and books (Aurrecoechea 2015). With a team consisting of cartoonists and academic consultants, they published the comic magazines México, Historia de un Pueblo ['Mexico, History of a People'], Novelas Mexicanas Ilustradas ['Illustrated Mexican Novels'], and Episodios Mexicanos ['Mexican Episodes'].

In the 1980s, the comic industry was dying out due to declining profitability. From 2000 on, comics have been used in different electoral campaigns to promote Mexico's presidential candidates. In 2000, Francisco Labastida Ochoa, of the Institutional Revolutionary Party (PRI), published Una Vida Ejemplar ['An Exemplary Life']. In 2006, Andrés Manuel López Obrador (nicknamed 'El Peje'), of the Party of the Democratic Revolution (PRD), featured as a superhero fighting corruption in PGman. In 2012, two presidential candidates used the comic genre: Gabriel Quadri, of the New Alliance Party (PANAL), adapted his campaign television spots to the comic's format, while Josefina Vázquez Mota, of the National Action Party (PAN), adapted her professional life to a comic book titled ¿Quién es Josefina? ['Who is Josefina?']. In the 2018 elections, José Antonio Meade, of the Institutional Revolutionary Party, Green Party, and New Alliance 
Party, published a comic book about his work in different governmental positions. In these same elections, the team of Andrés Manuel López Obrador (before being elected) published two comics: Un Aeropuerto que no Debe Aterrizar ['An Airport that Should Not Land'], expressing his disagreement with the construction of a new airport, and Pejenomics, presenting his economic project.

Government institutions have also employed the comic for social campaigns. For example, in 1997 and 1998, the National Council for the Prevention and Control of AIDS (CONASIDA) distributed the comic book Más Vale Prevenir ['It Is Better to Prevent'] among immigrants to the United States. El Libro Vaquero has published several governmental comic book editions, the most famous being the Guia del Migrante Mexicano ['Guide for the Mexican Migrant'], commissioned by the Ministry of Foreign Relations (SRE) in 2004. A recent case of using comics to address the Mexican population is Marihuana para Principiantes ['Cannabis for Beginners'], a propaganda comic book published in 2020 by the Hemispheric Institute, the legislator Jesúsa Rodríguez, and the activists Zara Snapp and Jorge Hernández; a group supporting the legalization of cannabis in México. The publication was promoted by the National Regeneration Movement Party (MORENA), a fraction of the Chamber of Senators.

\section{El Libro Vaquero as a vehicle of advertising and propaganda}

El Libro Vaquero survives from the last successful Mexican comic books phase, being in publication since 1978. At its peak, the magazine had a weekly circulation of 1,500,000 copies. Created by the cartoonist Rafael Márquez, it is set in the 1800s Mexicanized West and concerns cowboy stories about duels to the death, intrigues, and passions. One of its characteristics is that girls appear with sculptural bodies and sexy clothes (Fig. 1). Different companies owned the magazine over the years, such as Novedades Editores, Nueva Impresora y Editora, S.A. NIESA, and, more recently, HeVi Editores. According to the National Registry of Printed Media of the Mexican Government (2020), El Libro Vaquero currently has a circulation of 120,000 copies fortnightly. As for its readers, $28 \%$ are women, and $72 \%$ are men, $95 \%$ live in an urban area, and $5 \%$ in the countryside. The majority of them have a high-school education or a technical career (49\%), 39\% have an average standard of living and income, and 33\% are below average in both these variables.

The relationship between the Mexican government and El Libro Vaquero began years ago. The administration of Presidents Vicente Fox (2000-2006), Felipe Calderón (2006-2012), and Enrique Peña Nieto (2012-2018) utilized popular comic books to publish advertisements from at least 15 different institutions. Official political propaganda 
approaches a diversity of topics, such as property regularization, the prohibition of clandestine logging, family planning, and preventive information on diabetes (Proal 2009: 59). The comics we analyze here pertain to Enrique Peña Nieto's term of office. President Andrés Manuel López Obrador's government (2018) drastically reduced spending on official advertising, and no other official comics have been published to date.

Since 2010, HeVi Editores publishes comics for private companies and governmental institutions, a service known as custom publishing. The publisher's cartoonists create comics on the subjects requested by their clients, and these made-to-order comics are printed in El Libro Vaquero, supplementing the journal's typical Old West fare. HeVi Editores' LinkedIn (2020) page expressly states that these comics are made following the client's idea and message. The production cost of these made-to-order comics is between 100,000 and 200,000 Mexican pesos (appr. US\$ 5,000 and US\$ 9,000) (Murillo 2015).

In the social imaginary, El Libro Vaquero is associated with the popular classes, as it is considered low-quality reading. The dominant approach in Latin American academic studies of comics is Frankfurt School's first generation theory; specifically, Adorno and Horkheimer's conception of mass culture as mass-produced standardized cultural goods used to manipulate society and suspend critical thinking (Zubieta 2000:119). This perspective permeates studies such as Ariel Dorfman and Armand Mattelart's Para leer al Pato Donald [How to Read Donald Duck, 1971], and Irene Herner's Mitos y Monitos [Myths and Cartoons, 1979]. In the same vein, González Ponciano considers El Libro Vaquero a "manifestation of the low culture itself of functional illiterates, whose only relationship with the written text is reduced to this literature" (2012:220). Genaro Zalpa aptly points out that "using a circular argument, researchers have asserted that the popular classes are simple because they read comics and comics are simple because they are the favorite reading of the popular classes" (2005: 17).

Mexican comics have been the subject of other rigorous studies as well, such as by Juan Manuel Aurrecoechea and Armando Bartra (1993) or Anne Rubenstein (1998). However, the latter concludes that "Why bother studying Mexican comic books and the other trashy periodicals that sit beside them on newsstands? There are good reasons to think them trivial"' (Rubinstein 1998: 163).

Comics have been used as an educational or information resource (McLaughlin 2013; McNicol 2014), advertising material (Bugee 2016), or a vehicle for advancing social rights (Lent 2009; Mason 2009; Alshiban 2017). Although political communication in comic books has been analyzed (Brantner and Lobinger 2014), less attention has been paid to the comic's uses to spread governmental propaganda. Regarding El Libro Vaquero's uses, directly relevant to our project is Bruce Campbell's (2009) analysis of the Guia del Migrante Mexicano. 
Before proceeding with El Libro Vaquero's analysis, it is essential to clarify the difference between propaganda and social marketing as political communication types. As we have seen, the latter consists of employing marketing techniques to modify people's behavior or activities to achieve social good; therefore, it represents a modality of governmental communication. In contrast, propaganda seeks to gain support for a political party, a candidate, or an institution. Therefore, comics propaganda can be seen as a form of a permanent campaign that aims to manipulate people to engage in the act of governing itself (Kumar and Dhamija 2017:39).

Government-commissioned graphic narratives are found in other countries, as well. In Japan, for example, the manga is present in all facets of daily life: "television, advertising, product catalogs, fashion, or art; and it is used in education for informative or didactic purposes in informational brochures and manuals, as well as in academic and scientific writings, or in the representation of historical facts for educational use" (Santiago 2010: 270). In 2016, the Japanese Ministry of Defense published a manga inviting young people to join the Army in the face of a possible threat of Chinese expansionism and North Korean missiles. In its pages, "it sold the idea that becoming a military man can be attractive, cool and, in the case of women, sweet and sexy" (Robledo 2016). Also, on the Japanese island of Hokkaido, the authorities commissioned the illustrator Manabu Yamamoto to create a comic showing the population how to survive in case of a North Korean nuclear attack (Arana 2017).

\section{Analyzing El Libro Vaquero: individualization of responsibilities and the absence of structural causes}

The socio-semiotic approach (Verón 1998) recognizes the social dimension of any discourse: it is impossible to understand the meaning of any discourse if we do not consider the historical context in which that discourse was produced and received. To elucidate production conditions, we focused on the following rhetorical and thematic categories: the uses of stereotypes and the presence of what we call the 'institutional voice,' the absence of relevant information, the individualization of responsibilities, and the lack of thematizing structural causes. In our analysis, we considered the heuristic potential of each of these categories. Amongst the range of possible categories for investigation, we believe that the selected ones permit us to understand both the discursive construction of institutional comics and the representation of the commissioning institutions themselves.

Our analysis employs Luis Gasca and Román Gubern's definition of the stereotype as a simplified image or idea, stable and ritualized, which is widely accepted (1988: 27). By turning appearance into a sign of identity, a stereotype often carries deprecative 
connotations, that is, meanings appended to conventional figures that adjectivize them.

The institutional voice refers to a character who reaffirms the official discourse. While the narrator is situated outside the diegesis and interpellates the reader, characters are inside the diegesis, behind the fourth wall. However, in the institutional voice's case, we find a mixed type; this character type begins the story inside the diegesis and interacts with the other characters but, at some point, breaks the fourth wall and interpellates the reader. This modality reinforces the official discourse's main idea.

As for the absence of relevant information, we bore in mind what type of information would be appropriate according to the comic's title and the institution sponsoring the comic. As we've seen in the Introduction, this is a vital dimension of social marketing. If the goal is to change citizen's behavior, clear information is crucial to persuade them.

With individualization of responsibilities, we refer to cases where the main problem represented and its resulting solution are left in the citizens' hands. The state's role is obscure when society is defined as an aggregate of individuals, implying that society remains in the balance as long as they carry out their duties. Therefore, the state should only convey information to its citizens.

Finally, the absence of thematization of structural causes is correlative to the last category. If responsibility lies in the hands of the citizens, then the issue is always about individual responsibility. The role of structural factors -i.e., economic maldistribution, the lack of education and job opportunities, discrimination because of religion, ethnicity, sexual orientation, gender, language, and nationality - remains unaccounted for.

We analyzed four comics associated with governmental communication: Alimentos sanos y de Calidad a tu mesa ['Healthy and Quality Food at Your Home']; Ecobici. La Ciudad en Bici ['Ecobike. The City on a Bike']; Con agua crecida cuida tu Vida ['In Flood Times, Take Care of Your Life'], and El Libro Anticorrupción ['The Anticorruption Book']. As pointed out, Mexican comics reach many citizens, most of whom do not have access to state communications. They are in an advantageous position, then, to inform them about public policies, to educate, to gain support for a candidate or a political party, or to promote the image of specific institutions. In all these cases, the political content of comics corresponds to the propaganda type of political communication.

A brief note on the comics' stylistic dimension is also due. Institutional comics' authors often take for granted that these simply entail a juxtaposition of text and image (Beltrán 2009: 150). As a result, such comics usually have a relatively uncomplicated narrative, reduce the vignettes to mere illustrations of the accompanying text, and have very few speech balloons. In effect, they disregard most of the core elements of comics' graphic language: the iconography, the semantic utilizers of speech balloons, the grammar of framing, the mounting laws, the plot, and the storytelling, among others (Eco 2006: 155-160). 
El Libro Vaquero has remained one of Mexicans' favorite comics because, over the years, and despite employing several different cartoonists, it has maintained a distinctively dynamic drawing style. This contrasts sharply with the official comic books we analyze. Their drawings entail a clear line, flat colors, and simple treatment; that is, there is no use of kinetic resources, no shading, no volume effects, or color gradients. Captions (text boxes placed at the top of the vignettes) and speech balloons are visually heavy due to the large amount of information given to the reader. This textual overload attempts to compensate for the lack of plot in the stories. The vignettes are equally sized, and the dialogue appears outside the picture's space. Therefore, there is no dynamism, and there is a deficient use of framing. Occasionally, drawings seem disjointed, incapable of composing a situation; consequently, there is no other frame that graphically constructs another action.

\subsection{Healthy and Quality Food at Your Home}

The first governmental comic in our corpus was commissioned by the Ministry of Agriculture, Livestock, Rural Development, Fisheries, and Food (SAGARPA). The story narrates a day in the life of a character named José: he has breakfast with his family, goes to work in a meat-processing plant, and has dinner at home. In the different scenes and dialogues, there are descriptions of SAGARPA's activities and its specialized agency, the National Service for Agro-Alimentary Public Health, Safety and Quality (SENASICA). At work, José talks with the other characters about his job and his duties in securing good quality food (Fig 2).

The stereotypes in this comic correspond to the imaginary of rural Mexican people: José is tall, strong, has a mustache, short black hair, and is presented as the family provider. His image resembles the macho stereotype found in rural-themed 1940s movies. Similarly, his wife (who remains unnamed) appears in a traditional dress and braided hairstyle. Both are represented according to stereotypes created by the cinema of the Golden Age, which "marked a pattern in the social imaginary of what constitutes 'Mexicanity"' (Silva Escobar 2011:7). José functions as the vehicle of the institutional voice. After describing SENASICA's activities and importance, José turns to the reader and reiterates the importance of following the institutional requirements while holding an official document. As we can see in Figure 3, the official document occupies nearly one-third of the vignette.

This representation of the hierarchy of the bureaucratic duties consists of the information presented in the comic and corresponds to the comic's central theme: along with its story, the characters talk about the documents required by SENASICA and emphasize the importance of having the permit, without giving any more information about the latter. The story lacks two essential components, at least according to its title: to explain the importance of consuming 'healthy and quality food' and properly sani- 
tizing food. If we take this comic as a type of social marketing employed to achieve social good, it is evident that such information is necessary. Even more so, if we consider that Mexico has the second-highest obesity rate in the world (OECD 2017), with nearly $70 \%$ of Mexicans being overweight and almost one-third obese. There is no reference to the importance of a balanced diet, the benefits of consuming vegetables and fresh fruits, the adverse side-effects of beverage concentrates and highly processed food, or even to SENASICA's role in ensuring and certifying food safety and quality.

Concerning the individualization of responsibilities, it is essential to mention two interrelated items. The first is that, according to the dialogues among the characters, food producers must comply with all of SENASICA's requirements. Since nothing is said about how food can be considered healthy or not, the sole condition is to follow the bureaucratic procedure to certify their products. If a product receives the official seal of approval, it is considered sufficiently healthy (Fig. 4). In Mexico, small family farms are responsible for nearly $60 \%$ of agricultural production. Given the high rate of illiteracy and the complexity of the bureaucratic procedures outlined in the comic i.e., submitting a written solicitude, fulfilling the requirements of the SAGARPA health norms, undergoing several inspections, and being assigned an official Medical Veterinarian - it is evident that only a corporation can obtain the necessary certification. What happens in the meat-processing plant where José works is quite revealing. Half of the story takes place in this location; therefore, the comic's scenario induces semantic proximity between the character's daily life and the agroindustrial complex. It is the industrial entrepreneurs, not the small producers, that are shown to comply with the bureaucratic procedures. At the same time, José, the story's protagonist, is not a small or family producer but a salaried worker in the food industry.

The comic highlights SENASICA's crucial mission in ensuring food quality. For example, José explains to his wife and children the task of the institution. It does not explain, though, how SENASICA controls quality at the meat-processing plant where José works. The comic's propagandistic intention is clear: in over 32 pages, SAGARPA and SENASICA have a total of 13 mentions (counting balloon dialogues, text boxes, and logo inserts), equivalent to their presence in nearly $50 \%$ of the content. Besides, there is mention of the Government of México. In some vignettes, a trailer is visible in the background. The transport box's color is the one used in past official campaigns. It carries the official logo of the Government of Mexico next to the slogan México más Fuerte ['Strongest Mexico'], which features in Enrique Peña Nieto's administration's spots (Fig. 2 and 3). The comic's title suggests that it is about 'healthy and quality food.' Still, another aim is also evident: to spread and reinforce in the readers the positive image and importance of SAGARPA. 


\subsection{The Cyclist's Book. The City on a Bike}

The second comic, Ecobici. La ciudad en bici [Ecobike. The City on a Bike] was commissioned by Mexico City's government and concerned with its public bicycle system. Through forced dialogues between different characters who ride bikes throughout Mexico City, readers are informed about the Mexico City government's policies on this mode of transport: the existence of a program for the correct use of a bicycle and a manual for Ecobike policies, the expansion of bike paths, and improvements in the city's other public means of transport (Fig 5). The characters voice the institutional discourse with their conversations relaying the government's public policies.

Unlike the previous comic, here stereotypes are absent. Only the institutional voice is used, mainly through an unnamed police officer's character. Representing the category of the public functionary, he introduces the Manual del Ciclista Urbano [Manual of the Urban Biker] in the story and explains the government's public policies. In Figure 6, we observe that this character is represented just as José in the previous comic: holding the manual, he directly addresses the readers, once again breaking the fourth wall and placed outside the diegesis. In this case, moreover, we note another way of representing the official document. The manual held by the police officer is relatively small, but the following vignette zooms in on it. In the speech balloon, under the police officer, appears the web link to the manual.

Although there is ample information on the Mexico City government's public policies, some critical relevant information is missing. The comic says nothing about Mexico City's traffic problems, the lack of urban planning, high population density, the lack of public transport maintenance, or the over-concentration of jobs and medical services in specific areas. Moreover, it says nothing about air pollution, which is only implied by drawing a truck's exhaust emissions (Fig 7).

Concerning the individualization of responsibility, the narration stresses the necessity of using the bicycle as a clean alternative to cars. Therefore, the citizens are represented as those solely responsible for solving the current problems. All air pollution problems are reduced to a unique assumption: citizens must use bicycles more. These are those who must acquire the 'new bike culture.' But nothing is said about what produced air pollution: not the traffic, but the industries around Mexico City and the lack of urban planning, that is, the structural problems that led Mexico City to become one of the cities with the most air pollution are ignored.

In this comic, we find a mixture of social marketing and propaganda. On the one hand, there is a discourse that emphasizes the importance of riding bicycles instead of using cars; this activity is represented as having several benefits, such as reducing air pollution and citizens engaging in exercise. On the other hand, what prevails is a propagandistic dimension that includes several references to the Mexico City government's 
public policies. During the ride of Angélica and the police officer along Paseo de la Reforma Avenue, we observe a succession of Mexico City landmarks, such as the Angel of Independence, the Monument of the Revolution, and the Clock Tower of Polanco. Through these emblematic sites, the comic reiterates the history of Mexico City and its government's public works. Umberto Eco defines this feature as a continuum, meaning that "the montage of the story does not tend to solve a series of still frames in a continuous flow, as in the film, but to realize a kind of ideal continuity through a real discontinuity" (Eco 2006: 157-8). In the comic, this continuum corresponds to the city's routes. The artist drew this series of emblematic buildings to imply a continuity between static images that can be imaginatively perceived by the readers as a chain-inmotion. Thus, through the city's drawings and the characters' conversations, the comic reinforces a positive image of both Mexico City and its government.

\subsection{In Flood Times, Take Care of Your Life}

The third comic analyzed is Con agua crecida cuida tu vida [In Flood Times, Take Care of Your Life], paid for by the National Water Commission of Mexico (CONAGUA). The story is about a neighborhood situated in a risky zone, near a river. Amalia, one of the characters, does not want to go to the Mexican Civil Protection headquarters to obtain flood preventive information. When the flood takes place, she and her family manage to escape, but they lose all of their possessions. The Civil Protection officer, who helps them escape, stresses the importance of having preventive information when living in a risky zone.

In this comic, no stereotypes reveal class hierarchy - although the neighborhood people are portrayed with dark skin and living in precarious houses. But we do find the institutional voice, this time in the character of the (unnamed) Civil Protection officer, who explains the safety measures for avoiding damage from the flood and the importance of following the Civil Protection's instructions. At the end of the story, the officer directly addresses the readers, stressing that "listening to the authorities is a serious thing", while, in the background, the other characters express their agreement. All of these are outside the diegesis, but the officer is the one who assumes the identity of the institution: he is a public servant, his uniform displays the colors of the Mexican flag, and, while speaking, points authoritatively his finger at the reader (Fig. 8).

In this comic, we come upon the individualization of responsibilities correlated with total silence about the structural causes. The citizenry must be informed of the safety rules and obey the Civil Protection officers. The state, however, appears to have no other responsibility for the danger they face. It is obliged to provide information and shelter to those living in flood risk zones. Still, there is no mention of the lack of urban planning or infrastructure maintenance, or public housing policies. 
The risk zones referred to in this story are places where there are irregular settlements, often located in ecological reserves or city peripheries that lack the infrastructure or sanitary services. This problem is frequent in Latin America and other underdeveloped countries, which "are characterized by the existence of a large sector of the population that does not have the economic capacity or access to formal credit mechanisms to obtain a home" (González et al. 2003:182). Another major problem is the lack of state control.

The state's image as represented in the comic obscures all these failures. The comic demonstrates the state's presence and action in the orientation meetings (top vignette, Fig. 9), while the officers are represented as heroes. After the flood has taken place, we see them battling wind and rain to assist the flood victims (Fig. 10). It is noteworthy that this comic is the only one in which we find something similar to an antagonist: the flood itself, as a 'natural' and unpredictable disaster. The disregard of the structural causes also contributes to the individualization of responsibilities. The state is not represented as having other duties aside from providing information and shelter to the citizens. Its function is only palliative, not preventive. Focusing on the representation of the officers who play the institutional voice role, this comic corresponds to the propagandistic rather than the social marketing type of political communication. The narrative's central theme is the importance and tasks of CONAGUA and Civil Protection while obscuring state policies' inadequacies and failures.

\subsection{The Anticorruption Book}

The last comic we analyze is El Libro Anticorrupción ['The Anticorruption Book'], ordered by the Ethos think tank and Caucus Anticorrupción, a group made up of various Mexican legislators. In 2017, the comic was presented to the Chamber of Representatives. According to the press release, the publication aims to avert acts of corruption and to encourage citizen complaints (Animal Político 2017) (Fig. 11).

The story begins with Gabriel and Omar's characters, two young delivery men on their way to deliver an order to the Fonda de Doña Mónica. In Mexico, a fonda refers to a small, family-run restaurant, where the owners do everything, from cleaning and shopping for ingredients to cooking. To make time, they go down the wrong way of the street and are stopped by a traffic patrol. After bribing the police officer, the latter lets them go. Meanwhile, Doña Mónica, the restaurant's owner, talks with a man about the procedure to regularize her business after her husband's death. A woman named Diana appears in the restaurant, and Doña Mónica explains to her that, when she inquired about regularizing her restaurant, the civil servants requested money from her to carry out the procedure. At that moment, the delivery men appear and explain their delay by recounting the traffic patrol incident. Diana accuses Gabriel and Omar of being corrupt and acknowledges that "we can all be part of an act of corruption." The 
new National Anticorruption System, she explains, sanctions officials for engaging in acts of extortion and concludes with inviting (both characters and readers) to report acts of corruption (Fig. 12).

It is noteworthy that female characters are built via opposing stereotypes that tend to reinforce class discrimination. Doña Mónica bears the burden of being a darkskinned, poor widow. Diana, on the other hand, appearing in the story unexpectedly, is light-skinned and formally dressed. Although we know nothing about her, the way she questions the other characters and talks about legal matters indicates she may be a lawyer or a civil servant. Through their opposing representation, Diana is legitimized as the character who has all the necessary social and cultural authority to serve as the institutional voice. In this role, she makes explicit the position defined as individualization of responsibilities: "we can all be part of an act of corruption, either actively participating by offering money to officials, or wanting to 'facilitate procedures'" (Fig 13). Once again, responsibility is placed on the individuals, ignoring the structural factors that shape (informally, tacitly, and implicitly) everyday social practices and, in this case, involve coping mechanisms employed to deal with poverty, economic and social insecurity. This overlapping of inequalities between the ruling classes and those of the popular classes is reflected in Diana's first sentence: "We do not have to be corrupt just because they are." On this page, the graphic representation of her gaze at the reader serves to suspend the narrative's diegesis to interpellate the reader directly. Diana does not address Omar or Gabriel (as she does in the previous and subsequent pages) but

The Anticorruption Book is silent about the structural causes of corruption, which can be considered relevant information. The focus is solely on the citizens' actions and agency capacity, placing them on a plan that renders inequalities invisible while equalizing responsibilities. Simultaneously, the tone of Diana's speech, with its quasi-admonitory features, turns her into a moralizing character (Steimberg 2013:65).

Once again, we cannot consider this comic a type of social marketing; instead, it corresponds to propaganda. Throughout its pages, the comic reiterates the anti-corruption system's importance (although it is never fully explained) and the citizens' duty to denounce acts of corruption. However, nothing is said about corruption in politics or commerce and how it affects the citizens' daily life.

\section{Conclusion}

Mexican government's uses of El Libro Vaquero exhibit some essential common characteristics. First, the individualization of responsibilities appeared in all four comics studied: in the obligation of fulfilling the bureaucratic procedures to obtain the $S E$ NASICA seal-of-approval; in recommending bicycle-riding instead of driving cars; in obtaining flood preventive information and following the Civil Protection directives, 
and in denouncing acts of corruption. Second, in all four comics, the structural causes causing the problems represented are ignored. There is no mention of what has caused the deterioration in the dietary behavior of the Mexicans, no reference to the air contaminating activities of the industries around Mexico City or to the lack of urban planning and public housing policy. Similarly, there is no mention of the social inequalities that foster corruption at all levels, nor about the corruption in business and politics and its impact on the daily life of the Mexican population. Third, and somewhat expectedly, all four comics paint an unreservedly positive image of the commissioning institutions.

Focusing on institutional activities instead of providing clear and useful information while simultaneously obscuring the state's responsibility to solve the problems' structural causes, El Libro Vaquero's made-to-order comics operate as vehicles of governmental propaganda rather than as vehicles for social marketing. The mechanism through which they communicate institutional propaganda is multiple. The use of institutional voices is perhaps the most evident. Still, propaganda messages are also thematized through the dialogue balloons, the text boxes and the narration itself, and the visual representation of the institutional logos and the characters' stereotypical depiction.

Our analysis demonstrates the importance of studying the propaganda uses of comics, which are far more popular and widely read than other, more 'serious' publications and even national newspapers. However, in the case of custom publishing products, it is not the artists responsible for the stories but the state institutions that commission them. However, to what extent these state institutions achieve their propaganda objectives is an issue that demands future investigation.

\section{References}

Akbar M. Bilal, Jeff French and Alison Lawson 2019. A critical review of social marketing planning approaches. Social Business 9 (4): 361-392.

Alboury, Serge 1994. Marketing et communication politique. Paris: L'Harmattan.

Alshiban, Afra S. 2017. Saudi Arabia's Role in Advancing Comics. International Journal of Comic Art 19 (2): 51-77.

Animal Político 2017. ¿Un Libro Vaquero para entender (y combatir) la corrupción? Animal Politico, March 1. Available from: https: / / bit.ly / 2Owfajq [accessed May 30, 2020]

Arana, Ismael 2017. Japón publica un cómic manga con instrucciones para la población ante un posible ataque de Corea del Norte. El Mundo, November 3. Available from: https: / / bit.ly / 3qqAoNY [accesed May 30, 2020]

Associated Press 2005. La Biblioteca Pública de Denver veta las historietas El Libro Vaquero, El Libro Policíaco y otras dos. Crónica, August 26. Available from: https: / / bit.ly / 3aji03F [accesed June 30, 2020] 
Aurrecoechea, Juan Manuel 2015. La historieta popular mexicana en la hora de su arqueología. Tebeosfera cultura gráfica. Available from: https: / / bit.ly /37gmW7I [accessed January 13, 2021]

Aurrecoechea, Juan Manuel and Armando Bartra 1993. Puros cuentos. La historia de la historieta en México 1934 - 1950. México: Conaculta- Grijalbo.

Barker, Martin and Roger Sabin 2012. 'Doonesbury does Iraq': Garry Trudeau and the politics of an anti-war strip. Journal of Graphic Novels and Comics 3 (2): 127-142.

Barthes, Roland 1993. La aventura semiológica. Barcelona: Paidós.

Brantner, Cornelia and Katharina Lobinger 2014. Campaign Comics: The Use of Comic Books for Strategic Political Communication. International Journal of Communication 8: 248-274.

Bugge, Annechen Bahr 2016. Food advertising towards children and young people in Norway. Appetite 98: 12-18.

Campbell, B. 2009. Viva la historieta: Mexican Comics, NAFTA, and the Politics of Globalization. Univ. Press of Mississippi.

Coleman, Stephen 2012. Debate on television: The Spectacle of Deliberation. Television E New Media 14 (1): 20-30.

Cortsen, Rikke Platz, Erin La Cour and Anne Magnussen 2015. Comics and Power: Representing and Questioning Culture, Subjects, and Communities. Cambridge: Cambridge Scholars Publishing.

Cwalina Wojciech, Andrzej Falkowski and Bruce Newman 2011. Political Marketing. Theoretical and Strategic Foundations. London: Routledge.

Dougherty, Beth 2003. Comic Relief: Using Political Cartoons in the Classroom. International Studies Perspectives 3 (3): 258-270.

Eco, Umberto 2006 [1968]. Apocalípticos e Integrados. Trans.: Andrés Boglar, México: Tusquets Editores.

Eco, Umberto 2016. Tratado de semiótica general. Ciudad de México: Debolsillo.

Fuchs, Christian 2019. Nationalism on the Internet: Critical Theory and Ideology in the Age of Social Media and Fake News. London: Routledge.

Gobierno de la Ciudad de México 2020. ¿Qué es ecobici? Available from: https: / / bit.ly/3ahGqdX [accessed August 19, 2020]

Goncalves, Gisela and José Manuel Santos 2017. What ethics for governmental communication? Ethical issues on government public relations. Revista Internacional de Relaciones Públicas 14 (7): 165-182.

Gonzalez Ponciano and Jorge Ramón 2012. Entre el deseo y el pecado: sexismo y erótica pistolera en Frontera Violenta. In: Miguel Lisboa Guillén and Antonio Higuera Bonfil (eds.) El vigor de las imágenes. Miradas interdisciplinarias. México: Instituto de Investigaciones Antropológicas UNAM-PROIMMSE-Universidad de Quintana Roo, 217-236.

Henneberg, Stephan and Nicholas O'Shaughnessy 2008. Theory and Concept Devel- 
opment in Political Marketing: Issues and an Agenda. Journal of Political Marketing 6 (2): 5-31.

Hernández Nieto, L. N. 2020. Medicina y narrativas gráficas. [Conference presentation] Perspectivas disciplinarias y metodológicas en el estudio de revistas científicas mexicanas del siglo XX, Instituto de Investigaciones Bibliográficas UNAM, México.

Instituto de Seguridad y Servicios Sociales de los Trabajadores del Estado 2016. La obesidad en México. México: ISSSTE. Available from: https:/ / bit.ly/3rSjOqq [accessed July 15, 2020]

Jorge González Sánchez, Ignacio Kunz and Dulce María Barros y Ramosgarcía 2003. Uso residencial. In: Ignacio Kunz (ed.) Uso del suelo y territorio. Tipos y lógicas de localización en la Ciudad de México. México: Plaza \& Valdés, 173-186.

Kellner, Douglas 2009. Barack Obama and Celebrity Spectacle. International Journal of Communication 3: 715-741.

Kotler, Philip and Neil Kotler 1999. Political Marketing: generating effective candidates, campaigns, and causes. In: Newman, Bruce (ed.) Handbook of Political Marketing. London: SAGE.

Kruikemeier, Sanne 2014. How political candidates use Twitter and the impact on votes. Computers in Human Behavior 34:131-139.

Kumar, Amit and Somesh Dhanija 2017. A Contemporary Perspective on Political Branding and the Permanent Campaign. Rajagiri Management Journal 11 (1): 37-60.

Lamprinakou, Chrysa 2008. The Party Evolution Model: An Integrated Approach to Party Organization and Political Communication. Politics 28 (2): 103-111.

Lilleker, Darren 2006. Key Concepts in Political Communication. London: SAGE.

Lees-Marshment, Jennifer 2002. The Marriage of Politics and Marketing. Political Studies 49 (4): 692-713.

Lent, John A. 2009. Comics for Development and Conscientization. In: John A. Lent (ed.) Cartooning in Africa. New York: Hampton Press, 45-61.

Magnussen, Anne 2006. Imagining the dictatorship, Argentina 1981 to 1982. Visual Communication 5 (3): 323-344.

Mason, Andy 2009. Ten Years After: South African Cartooning and the Politics of Liberation. In: John A. Lent (ed.) Cartooning in Africa. New York: Hampton Press Inc, 247-302.

Mitaine, Benoit and Viviane Alay 2011. Lignes de Front. Bande Dessinee et Totalitarisme. France: George.

McLaughlin, Mark J. 2013. Rise of the Eco-Comics: The State, Environmental Education and Canadian Comic Books, 1971-1975. Revue de la culture matérielle 77 / 78: 9-20.

McNicol, Sarah 2014. Humanizing illness: presenting health information in educational comics. Med Humanit 40: 49-55.

Molla Ruíz-Gómez, Manuel 2006. El crecimiento de los asentamientos irregulares en áreas protegidas. La delegación Tlalpan. Investigaciones geográficas (60): 83-109. 
Murillo, Carmen 2015. El Makeover del Vaquero. Revista Expansión 9: 68-74.

Murtiningsih, Bertha Sri Eko 2017. Representation of 2004 General Election Campaign in Comics Media: Semiotics studies of Comic Ketopraktoon in the 2004 Election Campaign in Kompas Newspaper. Mediterranean Journal of Social Sciences 8(5): 117-129.

Núñez, Gonzalo 2012. 'El Libro Vaquero' mexicano seduce en Praga. Radio Prague International, June 27. Available from: https:/ / espanol.radio.cz/el-libro-vaqueromexicano-seduce-en-praga-8553225 [accessed July 13, 2020]

Ormrod, Robert 2008. A Conceptual Model of Political Marketing Orientation. Journal of Nonprofit \& Public Sector Marketing 4 (1): 47.64.

Organization for Economic Co-operation and Development 2017. Health at a Glance 2017: OECD Indicators. París: OCDE. Available from: https: / / www.oecd.org/ mexico / Health-at-a-Glance-2017-Key-Findings-MEXICO-in-Spanish.pdf_[accessed August 5, 2020]

Ormrod, Robert P. 2012. Defining Political Marketing. Management Working Papers. Aarhus University.

Packard, Stephen 2014. Comics E Politik/Comics E Politics. Germany: Christian A. Bachmann Verlag

Pickard, Victor and David Elliot Berman 2019. After Net neutrality: A New Deal for the Digital Age. United States: Yale University Press.

Pratkanis, Anthony 1994. Age of Propaganda: The Everyday Use and Abuse of Persuasion. United States: W H Freeman \& Co.

Proal, Juan Pablo 2009. Subsidio federal a las historietas chatarra. Proceso, Abril 5.

Robledo, Gonzalo 2016. El manga como arma de "paz proactiva” en Japón. El País, December 30.

Rodríguez Beltran, José Luis 2009. Análisis de los problemas expresivos del cómic. Revista Interuniversitaria de didáctica 10 (1): 149-159.

Rodríguez, Martín Diego 2005. Distribuye la SRE la guía del migrante en el Libro Vaquero. La Jornada, January 18.

Rosch, Felix 2013. 'Hooray! Hooray! the End of the World has been Postponed!' Politics of Peace in the Adventures of Tintin? Politics 34 (3): 225-236.

Rubenstein, A. 1998. Bad Language, Naked Ladies, and Other Threats to the Nation: A Political History of Comic Books in Mexico. Duke University Press.

Rundle-Thiele, Sharyn, Patricia David, Taylor Willmott, Bo Pang, Lynne Eagle and Rachel Hay 2019. Social marketing theory development goals: an agenda to drive change. Journal of Marketing Management 35 (1): 160-181.

Sanaa, Ilyas and Rasul Sarwet 2014. Women in Pakistani cyberspace: A sociosemiotic analysis of Facebook webcomics. Kashmir Journal of Language Research 17 (2): 209246.

Santiago, José Andrés 2010. Manga: del cuadro flotante a la viñeta japonesa. Pontevedra: Dx5 Digital \& Graphic Art Research. 
Secretaria de Gobernación de México 2020. Padrón Nacional de Medios Impresos. Available from: https: / / pnmi.segob.gob.mx [accessed July 23, 2020]

Secretaría de Salud 2015. La obesidad en el menor de edad. México: SS. Available from https: / / bit.ly/37fVBCs [accessed August 17, 2020]

Silva Escobar and Juan Pablo 2011. La Época de Oro del cine mexicano: la colonización de un imaginario social. Culturales 7(13): 7-30.

Steimberg, Oscar 2013. Leyendo historietas: textos sobre relatos visuales y humor gráfico. Buenos Aires: Eterna Cadencia Editora.

Vanderbeke, Dik 2010. In the Art of the Beholder. Comics as a Political Journalism. In: Berninger, Mark, Jochen Ecke and Gideon Haberkorn (eds.) Comics as a Nexus of Cultures: Essays on the Interplay of Media, Disciplines and International Perspectives. United States: McFarland.

Verón, Eliseo 1995. Semiosis de lo ideológico y del poder/La mediatización. Buenos Aires: Facultad de Filosofía y Letras, Universidad de Buenos Aires.

Verón, Eliseo 1998 [1993]. La semiosis social. Fragmento de una teoría de la discursividad. Trans.: Emilio Lloveras, Barcelona: Gedisa.

Yu, Pavlina S. 2020. Multimodal Text in Visual Political Communication. Russian Linguistic Bulletin 2 (22).

Woodcock, Pete 2006. The Polis of Springfield: The Simpsons and the Teaching of Political Theory. Politics 38 (2): 232-249.

Zalpa, Genaro 2005. El mundo imaginario de la historieta mexicana. México: Universidad Autónoma de Aguascalientes.

Zubieta, Ana María 2000. Cultura popular y cultura de masas. Conceptos recorridos y polémicas. Buenos Aires: Paidós.

\section{AUTHOR}

JIván Facundo Rubinstein Professor of Communication, Faculty of Political and Social Sciences, National Autonomous University of Mexico (UNAM).

\section{AUTHOR}

Laura Nallely Hernández Nieto Postdoctoral researcher, Institute for Bibliographic Research, National Autonomous University of Mexico (UNAM). 

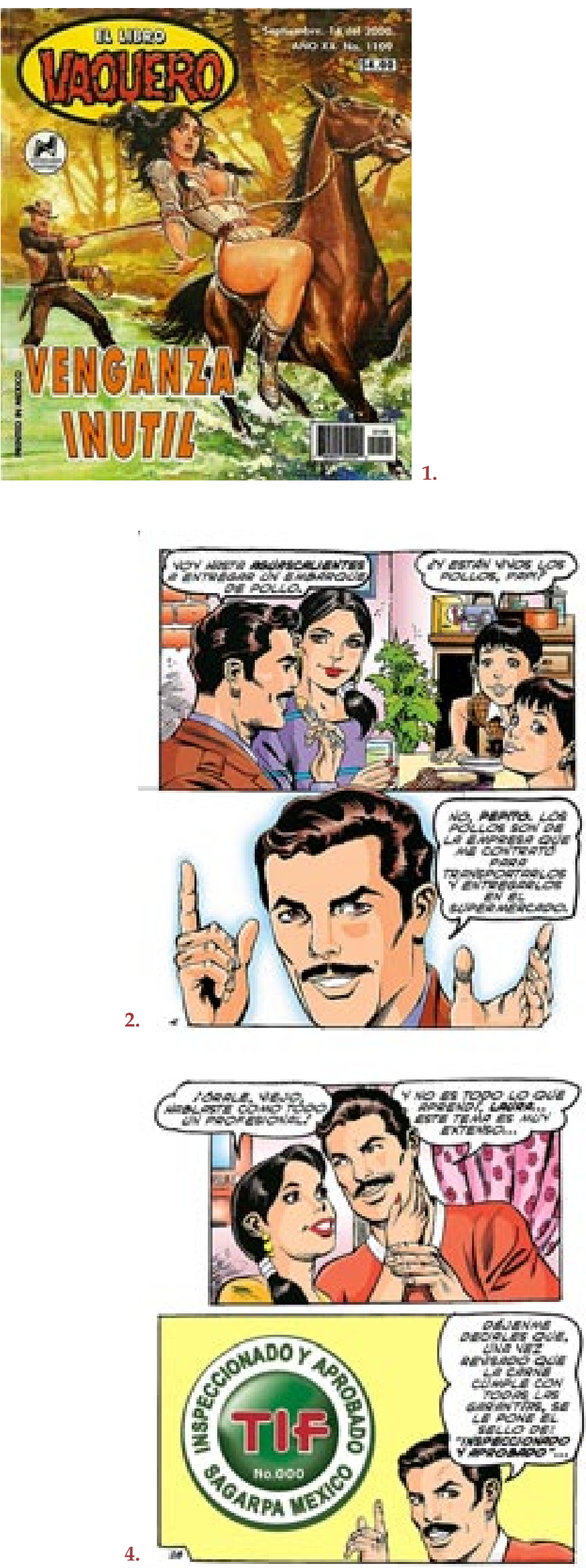

\section{LIST OF IMAGES}

Figure 1. Magazine cover of El Libro Vaquero ['The Cowboy Book']. Novedades Editores, Septiembre 14, 2000.

Figure 2. José explains his job and his duties in securing food of good quality. HeVi, August 25, 2014.

Figure 3. José holds an official document of SENASICA. HeVi, August 25, 2014.

Figure 4. José shows the importance of getting SENASICA's official seal-ofapproval. HeVi, August 25, 2014.

Figure 5. Cover of 'The Cyclist's Book. The City on a Bike'. HeVi, August 2, 2012.
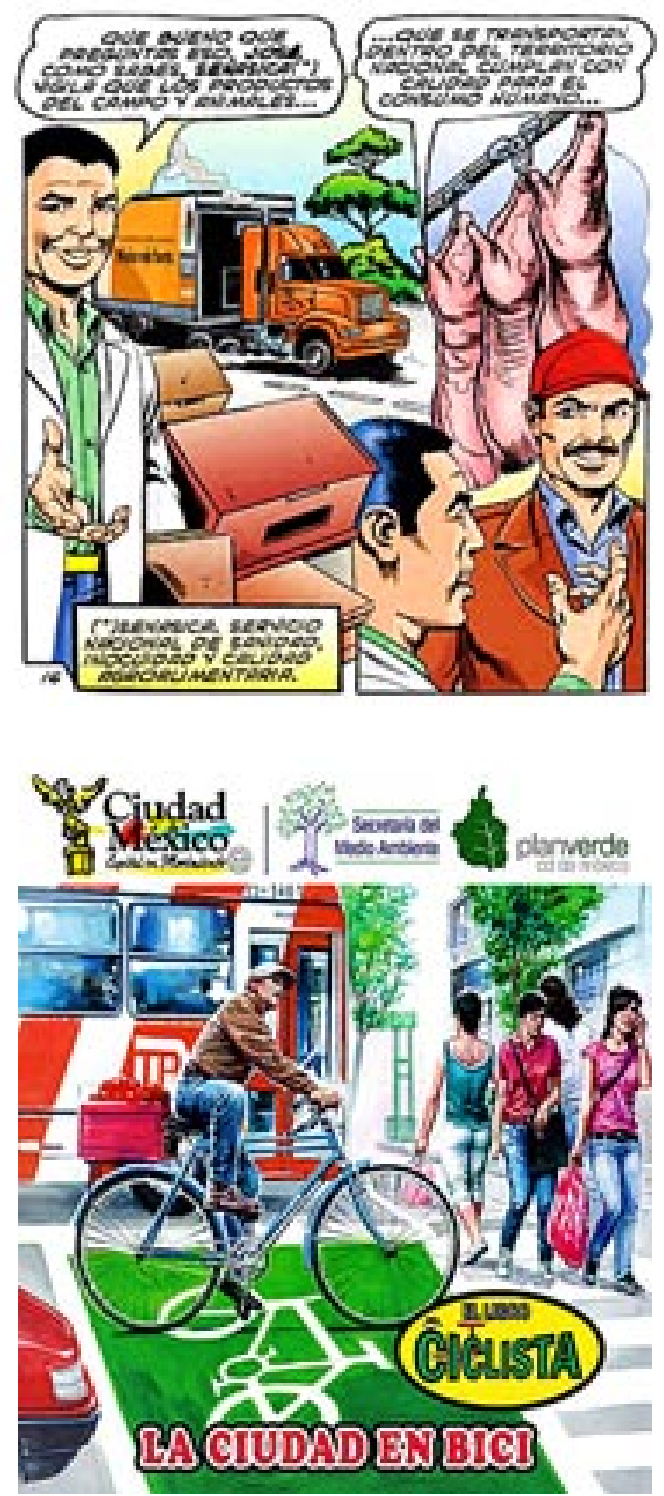
Governmental communication in Mexican comics. The case of El Libro Vaquero (C) 2021 Iván Facundo Rubinstein and Laura Nallely Hernández Nieto I Licenced under CC BY-NC-ND 4.0

Figure 6. The police officer introduces the Manual del Ciclista Urbano [Manual of the Urban Biker] to Angélica. HeVi, August 2, 2012.

Figure 7. Representing a truck's smoke emissions. HeVi, August 2, 2012.
Figure 8. The public servant as an institutional voice of CONAGUA. HeVi, August 28, 2014.

Figure 9. CONAGUA's orientation meetings in the risky zone. $\mathrm{HeVi}$, August 28, 2014.

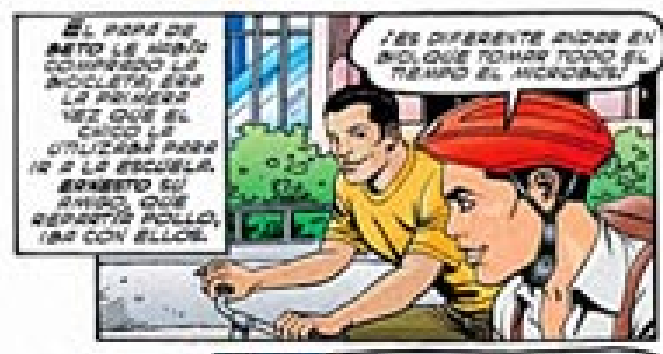

6.
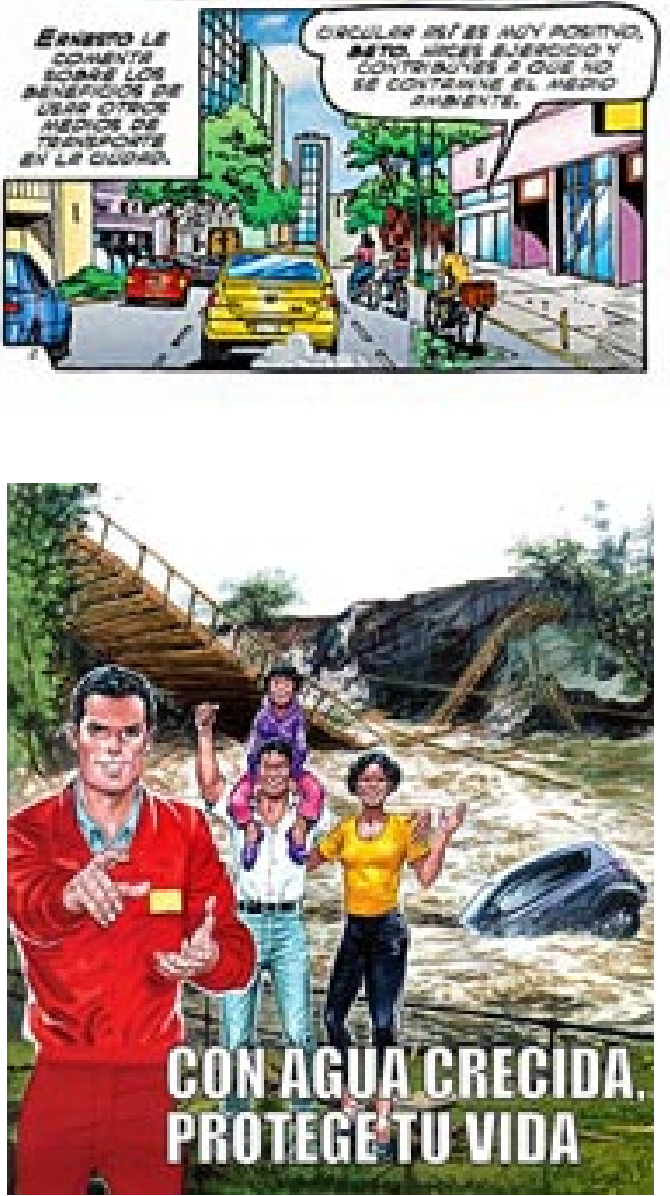
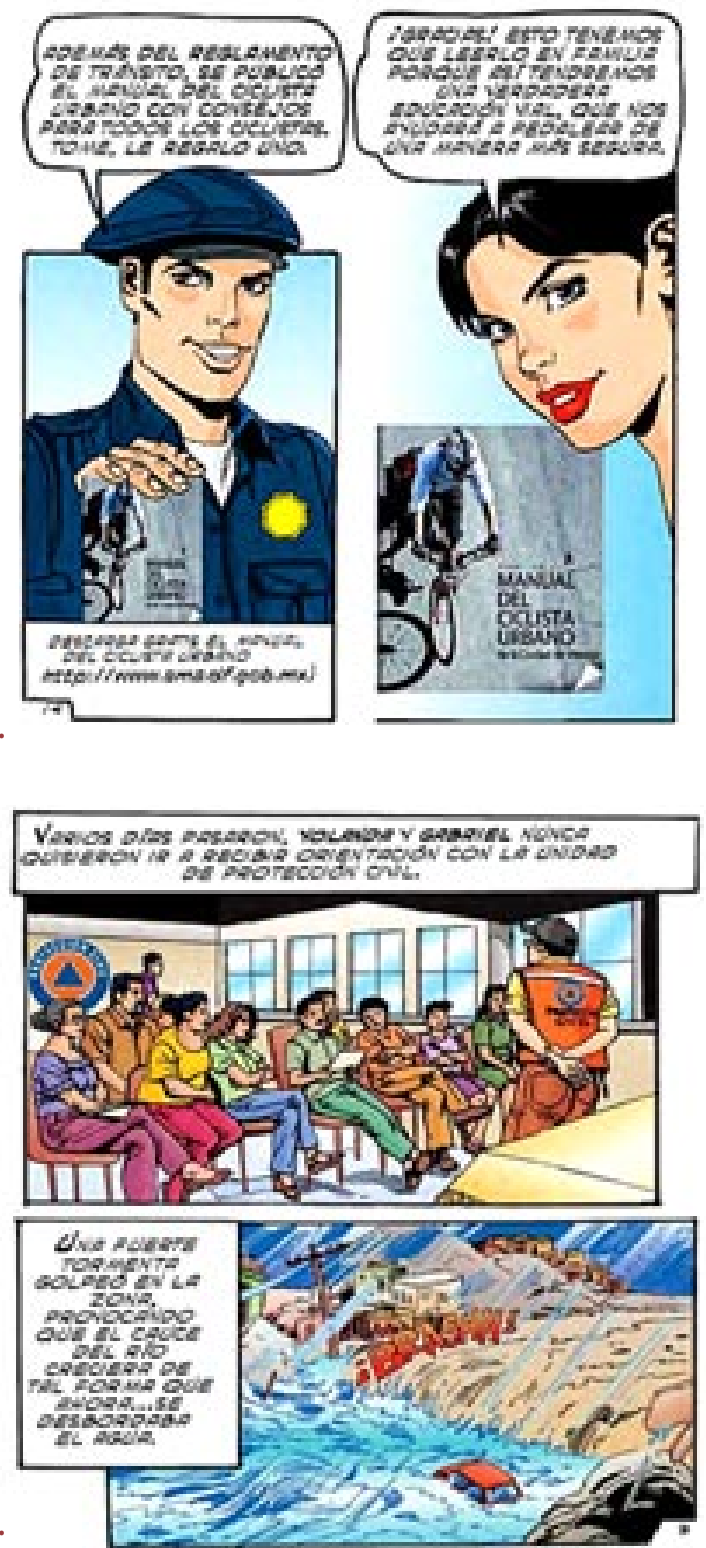
Figure 10. State offices as heroes who help people fleeing the flood. $\mathrm{HeVi}$, August 28, 2014.

Figure 11. Ethos and Caucus Anticorrupción logos in El Libro Anticorrupción [The Anticorruption Book], HeVi, February 15, 2017
10.

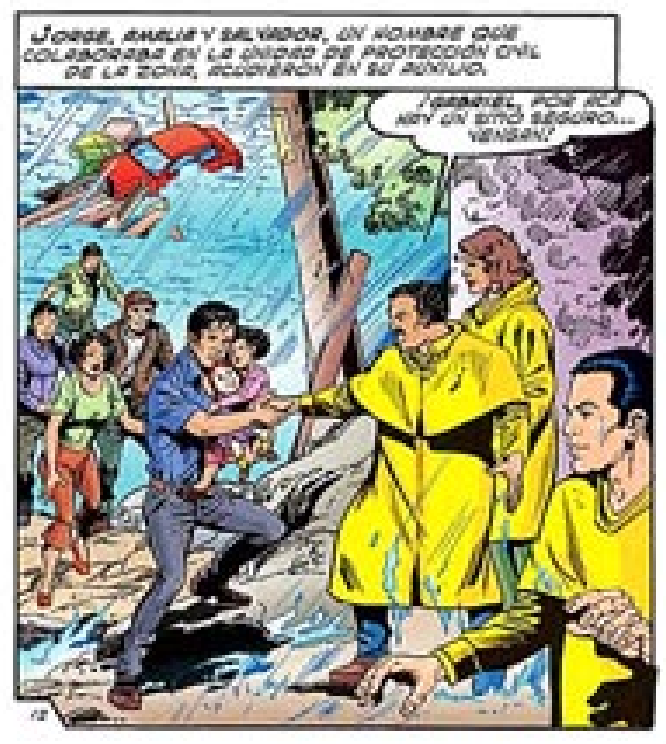

11.
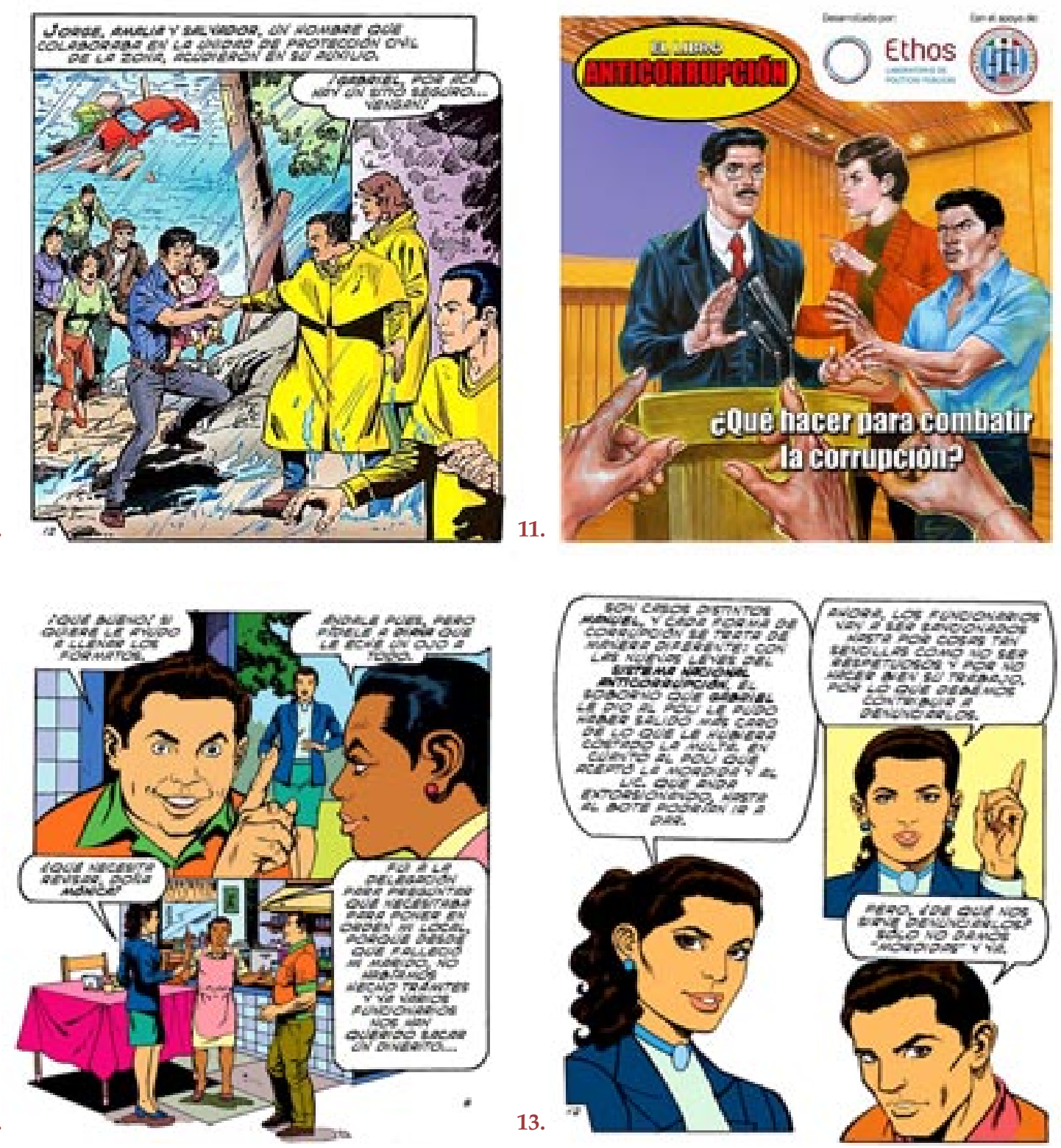

12.

13.
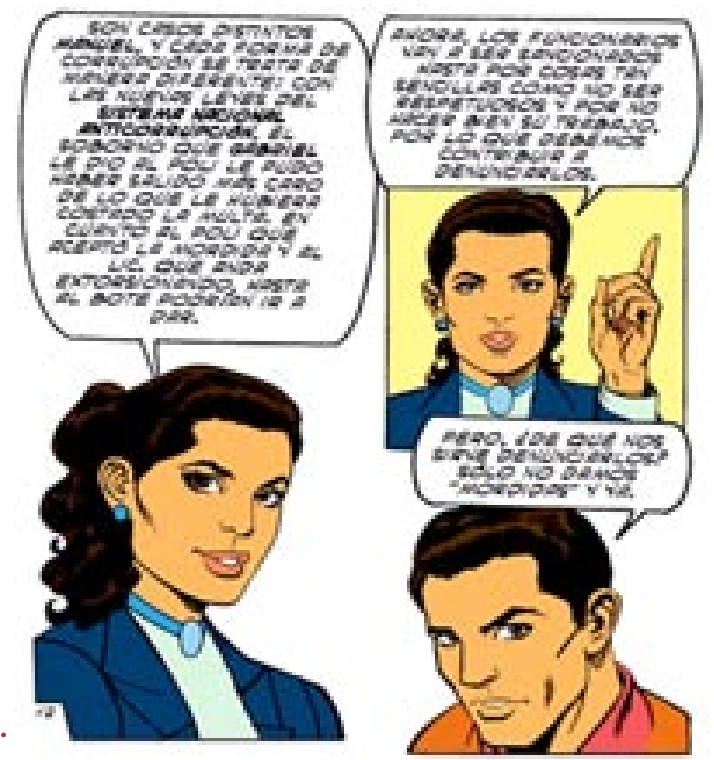

Figure 12. Diana points out that officials could be sanctioned for engaging in acts of extortion with the new National Anticorruption System HeVi, February 15, 2017

Figure 13. Diana as the institutional voice: "we can all be part of an act of corruption, either actively participating by offering money to officials, or wanting to 'facilitate procedures", HeVi, February 15, 2017 


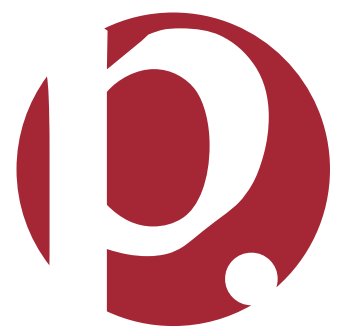

